Original research article

\author{
Dalibor Kesić* \\ University of Banja Luka \\ Faculty of Philology \\ Banja Luka, Republic of Srpska
}

\title{
IDEOLOGICAL MEANDERING IN TEXTUAL RENDERING: BINARITIES, INNUENDOS AND OVERTONES IN TRANSLATION
}

\begin{abstract}
The two essential components of translation are culture and language, and the inquiry into translation and translating lies in bringing together theory and practice in an interactive fashion. As it is essentially a linguistic exercise, the translation process needs to include a meticulous contemplation of all linguistic aspects of the text, including phonemic, morphological, syntagmatic, and semiotic facets. However, it would be naïve to believe that the list ends there. Political and ideological beliefs will not shape just the TL expressions and narratives translation too, will frequently reflect the translator's political affiliation or ethnic belonging. This paper selectively explores linguistic features that translators need to be alert about in their work. In conjunction with other considerations, including textual, phatic, cultural and stylistic, the translator's work definitely appears to be an informed act. In the analysis of text organization, in particular with relation to translation, the concept of semantic congruence comes to the fore. This being the case, the translator needs to be aware of the key textual mismatch between English and Serbian in order to produce acceptable TL renderings. His or her ability to move from parataxis to hypotaxis and vice versa constitutes an important component of their translatorial competence.
\end{abstract}

Key words: translation, meaning, ideology, influence, lexis

E-mail address: dalibor.kesic@flf.unibl.org 


\section{A broad overview}

Our social relations are largely contingent upon our compliance with different rules of a symbolic character that help us establish order and mutual understanding as rationally as we can. We use signs to convey and receive different information without which our efforts to transpose meaning from one language into another would be unimaginable. That is how all natural phenomena, from the cloud and the moon in bucolic poetry to fruit and plants in paintings, or apices in the texts of historians and politicians, get a new symbolic function and become material hubs that spin the thoughts and feelings to go beyond the individual, and beyond the social. The task of linguists remains to explain not only the categories of meaning, but also other fundamental categories, such as: sign, symbol, sense, communication and interpretation. Research into meaning ought to be pragmatic enough to encompass the issues of determination of specific meanings of individual types of symbolic activities, as well as determination of general conditions under which a certain utterance is socially communicable and intelligible to other members of the community regardless of whether it is being translated or not.

It is not easy to pinpoint which of the existing linguistic disciplines is supposed to delineate these matters. The ongoing paradigmatic change from equivalence-based theories to more functionally-oriented translation theories has had a significant influence on translation studies. In addition to contextual factors including text type, author, and audience, which usually figure heavily in linguistic and text-linguistic approaches to translation, the central role of the translator (whether acting individually or in association with a producer) has been underscored in more functionally-informed theories.

This invokes earlier attempts to depict the activity in a triangular fashion. That is why translation, according to Lefevere (1992) ought to be perceived as a process, product and reception. Translation refers to the product and reception, while translating refers to the process. Besides, translation can also be outlined as representation, transmission and transculturation (Tymoczko 2007). If translation entails all these determinants, it should then be observed through the prism of a responsive and wide-ranging theory married to good practice. The two fundamental components of translation are culture and language, and the inquiry into translation and translating lies in bringing together theory and practice 
in an interactive fashion. Because it brings the two together, the ideology and politics of translation and the architecture of information transmitted through language, the right approach to examining translation must take into account both phatic and referential elements of language, where one or the other will show some dominance without excluding the other.

Such a description can also apply to translation activity, where one strategy will exhibit domination while leaving enough space for others. The main objective of this paper is to spell out the doctrines relating to different translation theories in an attempt to form a multi-faceted and open-minded picture of translators' work. A well-versed translator cannot be asked to confine himself/herself to one translation strategy or paradigm, but instead they are likely to maneuver among them in pursuit of adequate solutions to issues. Thus, as Pym (2010: 166) observes:

When theorizing, when developing your own translation theory, first identify a problem - a situation of doubt requiring action, or a question in need of an answer. Then go in search of ideas that can help you work on that problem. Whatever approach or paradigm proves to be adequate, its aptitude may not be of an enduring nature and the perplexities of future circumstances may necessitate yet another shift.

Peter France points to the fact that theoreticians today have a far more complex task than the mere differentiation between what is good and what is bad; what they are concerned with nowadays is the different options that translators can utilize and the ways they can be adapted in conformity with the historical, sociological and cultural context (2000). Namely, globalization has also had its antithesis epitomised in the increased interest in one's cultural roots and one's own inherent identity. Thus, the translator, as the Irish theoretician Michael Cronin nicely described it, is also a passenger, one who roams from one culture to another (2000).

\subsection{Soaring above the micro-versus-macro dichotomy}

In the past two decades, one could observe an increase in the awareness "toward more sociologically- and anthropologically-informed approaches to the study of translation processes and products" (Inghilleri 2005: 125). For the sake of this paper's vistas, they might as well be referred to as 
macro level views, in particular those of Pierre Bourdieu, Niklas Luhmann and Bruno Latour. The end translation product will never assume a pure form, embracing wholly one theoretical orientation or another. Farghal (2012: 35) places the translator in the staple of a social game portraying the interaction between various agents in translation activity and goes on to show how the strategy of 'foreignization' might be adopted as a global strategy in translating a ST; however, the actual production of the TT will have to involve cases where the strategy of 'domestication' presents itself as a must, in order to avoid some communication breakdowns. By the same token, the micro covers all aspects of language. During the second half of the twentieth century, and so far in the twenty first century, there have been several series of shifts from morpheme to word, from word to sentence, from sentence to text, from text to context, from context to discourse, from discourse to genre, from language to culture and society, which necessitated an interdisciplinary interest between translation studies and sociology. Such a dynamic platform of theories indicates that there is no need to observe any one paradigm, and certainly no need to adhere to one exclusively.

This goes to show that there usually exists a heave of friction between several theoretically popular options at the macro level although they become more congruent and dynamic during the actual process of translation. The main weight, however, should be given to the relevance of macro issues such as culture, (master) discourse, genre, ideology, norms, and so on, prior to the actual translation process. That being said, one ought not to take the micro intricacies or restrictions lightly as they can have significant bearing on the work of translators. Translation never communicates in an untroubled fashion because the translator reconciles the linguistic and cultural differences of the foreign text by reducing them and supplying another set of differences, basically domestic, drawn from the receiving language and culture to enable the foreign to be received there. As such, translation emerges to be a cultural act, one that entails a certain level of manipulation given that it inherently involves a variety of stages in the process of transfer across linguistic and cultural restrictions. 


\section{Ideological divergence}

Human sciences aspire to reach the level of exactness that is present in exact sciences. Such an objective is easily spelt out and contrived, but far more difficult to truly achieve and materialize. Translation, like every activity that is heavily influenced by the human factor, is not immune to lateral centripetal influences that drive it away from axiomatic credentials. In approaching texts, translators are influenced, whether consciously or subconsciously, by their own beliefs, backgrounds, assumptions and the like; hence, their employment of certain linguistic devices, such as 'transitivity', 'cohesive device', 'over-lexicalisation', 'style-shifting', and so on (Hatim and Mason 1997: 143-163). Political substrates have generally been used in negative dogmatic terms mostly within the space of traditional Marxist explanations in which it is, "a form of cognitive distortion, a false or illusory representation of the real" (Gardiner 1992: 60). Namely, if one undertakes a meticulous segregation and fragmentation of expressions, notwithstanding larger semantic units and without due respect to cultural aspects of the given text any of the following issues can ensue - a) information can be misconstrued; b) the original text may not be sufficiently fathomed; or c) the internal relations within the expression may be deemed as lost altogether.

From an extreme point of view, one can even argue that the essence of the transference of meaning lies within the decomposition of the world as we know it. As a downright facet of translation, ideology is seen by Lefevere (1998: 41) as an approach through which readers in general and translators in particular approach texts. In such a world, translation becomes a necessity, particularly if we bear in mind that the cutting edge of translation is also the pillar of a culture, as Bhabhae described it metaphorically (Bhabhae 1994). Farghal (2008: 1) views translators' sociopolitical action as "superimposing certain directionality on the text in order to approximate it to, or even have it meet, their own or some other agent's goal".

One of the clear dilemmas that translators face in the case of Serbian into English translations comes to the fore when the need to translate the name of one of the two constituent entities in Bosnia and Herzegovina. Namely, the entity that in the Serbian language spells out as Republika Srpska is translated into English in two different ways: a) The Republic of Srpska, and b) Republika Srpska. This is not a mere choice whether to 
transliterate the original name or not. There is more political and ideological load to this than meets the eye. If the translator opts to translate it as The Republic of Srpska, just like any other republic is vocalized in the English language, the translator seems to be adding a layer of statehood that it does not really enjoy in its constitution and the Dayton Peace Agreement, for it is not really a republic, but rather an entity in the binary composition of the country. If the translator should opt to translate it as Republika Srpska however, they do not do it justice either, as, in that case, they seem to rely more on political rather than linguistic positions rendering it as the only Republika reference in the English language out of hundreds of other Republics. The famous German linguist Friedrich Schleiermacher would probably refer to this issue with his foreignizing versus domestication dichotomy, which will be more closely revisited in the following chapter.

\subsection{A tang of political innuendo}

The postcolonial view on the relations between the source and target text necessitates that the inequality of their status ought to be observed from several angles. The majority of scholars in translation studies and allied fields see ideology as "the tacit assumptions, beliefs, value system which are shared collectively by social groups" at a certain time (Hatim and Mason 1997: 144). What immediately comes to mind in the Republika Srpska/ The Republic of Srpska case is that fits nicely with the Schleiermacher'd dichotomy of domestication versus foreignization translation strategies referred to in the text above. For Venuti (1995: 20), the domesticating method is "an ethnocentric reduction of the foreign text to target language cultural values, bringing the author back home". There seems to be a close correlation between domestication and the so called fluent translation, whose main attribute is the use of terms which render the TT seamlessly palatable. It is straightaway perceptible and plain, "familiarized" and domesticated.

Foreignizing translation practices on the other hand, entail the choice of a foreign text and the invention of translation discourses. A foreignizing translator can use "a discursive strategy that deviates from the prevailing hierarchy of dominant discourses, but also by choosing to translate a text that challenges the contemporary canon of foreign literature in the target language". (Venuti 1995: 148). The choice whether to domesticate the entity's name into the English language and spell it out as The Republic 
of Srpska or to utilize the foreignizing strategy and render it as Republika Srpska without the preceding definite article is not bereft of political beliefs, for it is apparent that those who prefer to keep the entity away from the centralization of the whole country and retain its distinctive autonomy prerogatives lean towards translating it as The Republic of Srpska, while those who dream of seeing Bosnia as a centralized county without sovereign entity dividing lines in the future prefer to translate it as Republika Srpska. The preferences in this case seems to correspond to the translators' ethnical backgrounds.

A similar situation used to exist in the case of translating the name of Ukraine in the English language. There was a time when the majority of native English translators would opt to place the definite article in front of the name of the country, much to the disdain of native Ukrainians who objected to the use of the definite article on account of it diminishing its independence conspicuousness. As the time lapsed and as the country leant closer and closer to the western political sphere, the definite article before the name of the country in the translations by western translators began to fade away, until its near complete elusiveness in the current translations. One can surmise that some translators, having their own beliefs and conviction, or even political affiliations, not only add, omit, shift, modulate, undertone, euphemize, understate or exaggerate, but also actively engage in the so called "naming strategy", in which they opt for one type of name over another (Simpson 1993: 141), in order to consciously or subconsciously produce a TL text which is more in conformity with a local political agenda or innuendo.

As far as the relationship between the source culture and target culture is concerned, it is worth noting that they seldom dwell on equal platforms. Robyns (1994: 120, 409) argues that the target culture is prone to taking a certain attitude regarding the source culture which can be described as part of one of the following scenarios: a) the target culture encourages transporting foreign materials from the source culture, provided that the transported materials are naturalized in accordance with the established systems of the target culture and its norms and conventions - which can rightfully be described as imperialistic; b) the target culture regards the source culture as a threat to its identity, thereby avoiding any influence the target culture might exercise - a defensive stance; c) the two cultures see each other equally - a trans-discursive dichotomy; or d) the target culture looks at the source culture as a capable culture that can compensate for target cultural deficiencies - defective. 
These seemingly opposing attitudes have existed for as long as the writings on translation, from Cicero and Horace to Munday and Baker. Consequently, no matter what the relationship between the interfacing cultures is, whether imperialistic, defensive, trans-discursive, or defective, there will always be a certain level of influence on the translator prior to undertaking the actual act of translating. That being said, the influence may well reach its summit when the relationship is imperialistic whereby the target culture adopts a colonial approach in transporting the foreign materials (Almanna 2014: 98). The question that arises here is whether the translator, the editor, the producer or the purveyor of the translation has the right to interfere ideologically and steer the TT towards different goals.

\subsection{Stereotypical beliefs and emblematic outputs}

Such an imperialistic relationship between the source and the target cultures has encouraged the translation of literary works that are in line with the existing stereotypical representations summoned up in the target readers' thoughts towards the original countries of origin notwithstanding of the literary quality of the texts. That might explain why some western countries are so much in love with literary works that are of a controversial nature in their countries of origin - usually those that deal with some sort of sedition, blasphemy, feminism or human rights which conveniently feed into the target culture's stereotypical narratives.

A tang of controversy always adds a bit of honing and a convenient cutting edge. The only Nobel Prize ever awarded to any literary work from the territory of the former Yugoslavia was given to The Bridge on the Drina novel by Ivo Andrić. Its literary endowments indisputable, the controversial plot in the current political terms was another potential garnish to be scored. Perhaps an even better example is the only Oscar winning film from the same territory - No Man's Land. There is a widespread belief that its poor artistic prowess was only rewarded for its plain political biasness, apparently much appreciated by the Academy jury. Ideological preponderance is pervasive and ubiquitous, and as Pinchuck puts it 'words are a means of expressing an idea or conveying a message, while the purpose of communication is what guides their conventionality. They function under strong restrictions and offer some resistance to individual manipulation. Words are means, but means with peculiar properties' (1977). 


\section{Conclusion}

A comprehensive consideration of the diversity of different approaches to translation eventually leans towards its functionality. In other words, every translation ought to start from the contemplation of the purpose it is meant to serve in the target language, or at least that is what the translation skopos urges us to do. On the one hand, translation activity may be viewed as a transmitting entity based on a sacred original, where the translator functions as a mere mediator. On the other hand, translation activity may be regarded as an originating entity based on the skopos of the translation, where the translator acts as a free go-between. In-between, there are a host of cases in which differing judgments can be passed.

Being both the ST receptor and the TT sender, the translator is involved in a number of tasks, such as reading, analyzing, interpreting, comprehending, transferring, restructuring, adapting, improving, evaluating, and so on (Bell 1991; Belhaaj 1998). Pondering the SL meaning as the etalon of the TT accuracy inexorably leads to the conclusion that meanings have metamorphosing and alternating roots and different paths of genesis. They take us into unexplored and uncharted waters of primordial experience. Words, on the other hand, are quintessential symbols. They owe their power to the fact that they link the semantic content with the presemantic depths of human experience and the two-dimensional structure of symbols. Lack of transparency of symbols combined with the strife to translate them exactly seems to pose an unsolvable problem which lies in the fact that all symbolic meanings are indeed deeply rooted in the realm of our individual and collective experience. This becomes apparent when certain formulations are phatic in nature, and translating them this way or another significantly changes the political and ideological output. In extreme cases, the ethnic belonging of the translator may become obvious just by the option they chose.

While, in the past, the preponderance of scientific research was placed on the comparison of the original with the product of translation, often with the latent aim to discover what has been 'lost' in translation, in the current, poststructuralist approach there seems to be a dramatic turn so that the ultimate aim is no longer to evaluate but rather to understand what has happened during the process of translation of meanings with ideological or political load when transferring them from one ideological system into another.

The bond between ideological beliefs, thoughts and language is even more intimate than commonly believed. It is not about first mentally 
translating a formulation, only to express it in the TL subsequently, thus making it accessible to others. Once formed, it goes on to exert influence on the thinking of each individual in the given community, as well as on the further course of its cultural creativity. Cassirer highlights the following fact of importance in consideration of the relation between language and thought: "Learning to name objects, a child does not simply add one sign on top of another. It actually learns to form notions for those objects, in order to comprehend the objective world... Without the facility of the name, every new progress in the objectification process would be lost again already in the following moment." (Cassier 1944: 132). In addition, there are facets of language that will have an impact on the faithfulness of translation too. The character and wealth of its lexis, peculiarities of its grammar and syntax seem to be in full conformity with the experience of human practice in given natural and societal circumstances.

\section{References}

Almanna, A. (2014). Translation Theories Exemplified from Cicero to Pierre Bourdieu. Munich: Lincom Europa.

Cassirer, E. (1944). An Essay on Man: An Introduction to a Philosophy of Human Culture. New York: Yale University Press.

Belhaaj, A. E. (1998). The Process of Translation: Factors, Tasks and Challenges. Saudi Arabia: Umm Al-Qura University Press.

Bell, R. (1991). Translation and Translating: Theory and Practice. London/ New York: Longman.

Bhabha, H. (1994). The Location of Culture. London/New York: Routledge.

Cassirer, E. (1944). The concept of group and the theory of perception. Philosophy \& Phenomenological Research, 5, 1-35.

Cronin, M. (2000). Across the Lines: travel, language, translation. Cork: Cork University Press.

France, P. (2000). Translation Studies and Translation Criticism. In: P. France (ed.), The Oxford Guide to Literature in English Translation, Oxford: Oxford University Press, 3-10.

Inghilleri, M. (ed.) (2005). The Sociology of Bourdieu and the Construction of the 'Object' in Translation and Interpreting Studies. The Translator, 11(2), 125-145. 
Farghal, M. (2012). Advanced Issues in Arabic-English Translation Studies. Kuwait: Kuwait University Press.

Farghal, M. and M. Al-Hamly (2010). Remodeling in Kuwaiti Newspaper Commentary Titles. Annals of the Arts and Social Sciences, 319(31), 46.

Gardiner, M. (1992). The Dialogics of Critique: M M Bakhtin and the Theory of Ideology. London: Routledge.

Hatim, B. and I. Mason (1997). The Translator as Communicator. London/ New York: Routledge.

Lefevere, A (1992). Translation, Rewriting and the Manipulation of Literary Frame. London/New York: Routledge.

Lefevere, A. (1998). Translation Practice(s) and the Circulation of Cultural Capital: Some Aeneids in English. In: S. Bassnette and A. Lefevere (eds.), Constructing Cultures, Clevendon: Multilingual Matters, 40-56.

Pym, A. (2010). Exploring Translation Theories. London/New York: Routledge.

Simpson, P. (1993). Language, Ideology and Point of View. London: Routledge.

Robyns, C. (1994). Translation and Discursive Identity. Poetics Today, 15(3), 405-428.

Tymoczko, M. (2007). Enlarging Translation, Empowering Translators. Manchester, UK and Kinderhook, NY: St Jerome Publishing.

Pinchuck, I. (1977). Scientific and Technical Translation. London: Andre Deutsch Ltd.

Venuti, L. (1995). The Translator's Invisibility. London/New York: Routledge.

Received: 28 May 2019

Accepted for publication: 18 June 2020 
Далибор Кесић

\section{ИДЕОЛОШКЕ СЕРПЕНТИНЕ У ПРИРЕБИВАЮУ ТЕКСТА: БИНАРНОСТИ, АЛУЗИЈЕ И НАТУКНИЦЕ У ПРЕВОДИМА}

\section{Сажетак}

Два неизоставна елемента у сваком преводу су култура и језик, док се подробније истраживањепревода и превођења своди назближавање теорије и праксе на интерактиван начин. С обзиром да је у питању суштински лингвистичка област, процес превођења треба да укључи минуциозно разматрање свих лингвистичких аспеката унутар текста, укључујући фонемске, морфолошке, синтагматске и семиотичке аспекте. Међутим, било би наивно вјеровати да се списак ту и завршава. Политичка и идеолошка убјеђења не утичу само на изразе и нарацију унутар изворног језика - преводи такође често одају преводиочеве политичке афилијације или етничку припадност. Овај рад селективно разматра лингвистичка обиљежја на која преводиоци треба да обрате посебну пажњу у свом раду. Заједно са осталим разматрањима, укључујући, текстуална, фатичка, културолошка и стилистичка, рад преводиоца дефинитивно има обиљежја информисаног чина. Приликом анализирања организације текста, поготово у погледу превођења, концепт семантичке усклађености долази до изражаја. У таквој ситуацији, преводилац треба да буде свјестан кључног текстуалног неслагања између енглеског и спрског језика како би се остварило прихватљиво уобличавање текста у циљном језику. Преводиочева способност да начини отклон од паратаксе у корист хипотаксе, и обрнуто, чиниће битан дио његове преводилачке компетенције.

Кључне ријечи: превођење, значење, идеологија, утицај, лексика 